\title{
PENGUATAN (REINFORCEMENT) VERBAL DAN NONVERBAL GURU DALAM PEMBELAJARAN BAHASA JEPANG DI KELAS XI MIPA 2 SMA NEGERI BALI MANDARA
}

\author{
N. W. A. Cahyani ${ }^{1}$, G. S. Hermawan ${ }^{2}$, D. M. S. Mardani ${ }^{3}$. \\ ${ }^{123}$ Jurusan Pendidikan Bahasa Jepang, Universitas Pendidikan Ganesha, Singaraja,Bali \\ e-mail: cahyaniayu73@undiksha.ac.id \\ desak.mardani@undiksha.ac.id satya.hermawan@undiksha.ac.id
}

\begin{abstract}
Abstrak
Penelitian ini bertujuan untuk mendeskripsikan (1) model-model penguatan yang digunakan oleh guru dalam pembelajaran bahasa Jepang di SMA Negeri Bali Mandara. (2) penggunaan bahasa Jepang dalam penguatan oleh guru dalam pembelajaran bahasa Jepang di SMA Negeri Bali Mandara. Subjek dalam penelitian ini adalah guru bahasa Jepang di SMA Negeri Bali Mandara. Pengumpulan data dilakukan dengan metode observasi, dokumentasi, dan wawancara, kemudian dianalisis menggunakan metode deskriptif kualitatif. Hasil penelitian ini adalah (1) Model-model penguatan yang digunakan oleh guru dalam pembelajaran bahasa Jepang di SMA Negeri Bali Mandara adalah penguatan verbal, nonverbal dan kombinasi penguatan verbal dengan nonverbal. Penguatan verbal yang digunakan adalah kata dan kalimat. Penguatan nonverbal yang digunakan adalah senyuman, gerak badan (gestural) menganggukkan kepala, mendekati siswa, dan kegiatan menyenangkan seperti menonton anime. Kombinasi penguatan yang digunakan adalah kombinasi penguatan verbal dan nonverbal berupa senyuman dan menganggukkan kepala. Model-model penguatan tersebut digunakan dalam bentuk pujian, dukungan, pengakuan dan penghargaan serta dalam bentuk teguran dan nasihat. (2) Penggunaan bahasa Jepang dalam penguatan yang dilakukan oleh guru dengan cara menggunakan penguatan bentuk verbal dalam bentuk pujian, dukungan, pengakuan dan penghargaan berupa "Hai", "Hai ii desu", "Hai sou desu", "Sugoi desu", "Yoku dekita", "Daijyoubu desu", Arigatou gozaimashita", dan Otsukaresamadeshita" serta memberikan penguatan dalam bentuk nasihat atau teguran berupa "Diam-diam shizukani" dengan campur kode bahasa Indonesia dan bahasa Jepang.
\end{abstract}

Kata kunci: Bahasa Jepang, Model Penguatan, Pembelajaran, Penguatan

要旨

本研究目的は、バリマンダラ高校の日本学習において 1 ）教師が使用した強化モデル 2 ）教師が使用 した強化の日本語言葉の使いを説明する。調査協力者は、バリマンダラ高校の日本語の教師である。 調査方法は、観察、インタビュー及び、文献調査である。収集したデータを定性的記述法により分析 した。その結果、1）教師が使用した強化モデルは口頭、非言語、口頭と非言語的の組み合わせの応 用モデルである。使用した口頭強化は言葉と文書である。使用した非言語的強化は笑顔、ジェスチャ 一（うなずき）、学生に近づく、そして楽しい活動をすることである（アニメを見る）。使用した組 み合わせの応用は口頭と非言語的の組み合わせである。例えば笑顔とジェスチャー（うなずき）であ る。教師が使用した強化モデルは観賞、サポート、自白、賞美、そして警告とアドバイスである。2 ）教師が使用した強化の日本語は観賞、サポート、自白、賞美の形で口頭強化は言葉を使用した。例 えば“はい”、“はい、いいです”、“すごいです”、“よくできた”、“大丈夫です”、“ありが とうございました”、“おつかれさまでした”である。そして警告又はアドバイスの形でインドネシ ア語と日本語を混在コードは“Diam-diam しずかに“である。

キーワード：日本語、強化モデル、学習、強化

\section{Pendahuluan}

Pengutan(reinforcement) merupakan bagian dari 8 keterampilan mengajar yang harus dimiliki oleh seorang guru dan mampu diterapkan dengan baik dalam proses pembelajaran. Delapan keterampilan mengajar yang dianggap memiliki peranan penting dalam keberhasilan kegiatan belajarmengajar meliputi (1) keterampilan bertanya, (2) keterampilan memberikan penguatan, (3) keterampilan mengadakan variasi, (4) keterampilan 
menjelaskan, (5) keterampilan membuka dan menutup pelajaran, (6) keterampilan membimbing diskusi kelompok kecil, (7) keterampilan mengelola kelas, (8) keterampilan mengajar kelompok kecil dan perorangan (Turney, 1973). Dapat dikatakan bahwa penguatan merupakan salah satu faktor penting sebagai penentu keberhasilan siswa dalam pembelajaran.

Pemberian penguatan baik secara verbal dan nonverbal yang dilakukan guru dalam setiap pembelajaran mampu membuat siswa lebih termotivasi, lebih aktif, lebih antusias, dan senang dalam menerima pelajaran, serta siswa merasa dihargai di setiap keaktifan yang telah dilakukannya (Utami, 2015). Selain itu, seperti penelitian yang telah dilakukan oleh Aryawan (2017) yang menemukan bahwa, jika dilihat dari pembelajaran bahasa Jepang, penguatan juga dapat menambah pengetahuan siswa mengenai kosa kata, pola kalimat, dan budaya Jepang. Sehingga hal ini dapat melatih siswa dalam belajar dan menggunakan bahasa Jepang secara langsung. Berdasarkan penjelasan yang telah dipaparkan, maka perlu bagi guru untuk menerapkan dan mengembangkan penguatan dalam kegiatan pembelajaran sebagai upaya untuk menumbuhkan, menjaga dan meningkatkan motivasi siswa dalam belajar yang telah diupayakan implementasiannya oleh guru bahasa Jepang di SMA Negeri Bali Mandara.

Hal tersebut dapat dilihat dari pengalaman PPL-Real yang telah dilakukan di SMA Negeri Bali Mandara. Guru bahasa Jepang di SMA Negeri Bali Mandara menerapkan keterampilan memberikan penguatan dalam pembelajaran. Salah satu contoh ketika guru memberi penguatan kepada siswa. Penguatan yang diberikan baik berupa penguatan verbal dan nonverbal, seperti "li desu, oke" mendekati, tersenyum dan lain sebagainya. Penguatan terdiri dari dua, yaitu penguatan verbal dan penguatan nonverbal yang bertujuan untuk membesarkan hati siswa agar lebih semangat dan aktif dalam proses pembelajaran (Usman, 2005). Penguatan positif untuk tingkah laku siswa yang baik sehingga perlu dipertahankan selama proses pembelajaran dan penguatan negatif untuk tingkah laku siswa yang kurang baik di dalam kelas, sehingga kegiatan tersebut dikurangi atau dihilangkan dalam proses pembelajaran.

Berdasarkan penjelasan tersebut, maka muncullah ide penelitian mengenai penguatan verbal dan nonverbal oleh guru dalam pembelajaran khususnya dalam pembelajaran bahasa Jepang. Penelitian sejenis pernah diteliti oleh Aryawan (2017). Penelitian ini mengenai penguatan dalam pembelajaran bahasa Jepang oleh guru bahasa Jepang SMA Negeri 1 Sukasada sedangkan penelitian ini mengenai penguatan verbal dan nonverbal guru dalam pembelajaran bahasa Jepang di kelas XI MIPA 2 SMA Negeri Bali Mandara sehingga penelitian ini layak untuk diteliti. Permasalahan yang akan dibahas dalam penelitian ini yaitu: Apa model-model penguatan yang digunakan oleh guru dalam pembelajaran bahasa Jepang di kelas XI MIPA 2 SMA Negeri Bali Mandara? dan Bagaimanakah penggunaan bahasa Jepang sebagai penguatan verbal oleh guru dalam pembelajaran bahasa Jepang di kelas XI MIPA 2 SMA Negeri Bali Mandara?

\section{Metode}

Penelitian ini menggunakan pendekatan deskriptif-kualitatif. Menurut Dantes (2012:51) penelitian deskriftif adalah suatu penelitian yang berusaha mendeskripsikan suatu pristiwa/fenomena secara sistematis sesuai dengan apa adanya. Menurut Bungin (2009:68) penelitian deskriptif kualitatif merupakan penelitian yang bertujuan untuk menggambarkan, meringkaskan, berbagai kondisi, berbagai situasi, atau berbagai fenomena realitas sosial yang ada di masyarakat yang menjadi objek penelitian, dan berupaya menarik realitas itu ke permukaan sebagai suatu ciri, karakter, sifat, model, tanda atau gambaran tentang kondisi, situasi atau fenomena tertentu. Dengan demikian, dapat dikatakan bahwa penelitian deskriptif-kualitatif adalah penelitian yang digunakan untuk memperoleh gambaran yang jelas mengenai kondisi, situasi, dan fakta-fakta yang didapat dari lapangan atau objek penelitian. Penelitian ini dilakukan di SMA Negeri Bali Mandara yang berlokasi di Jalan Air Sanih, Desa Kubutambahan, Kecamatan Kubutambahan.

Sumber data dapat dibedakan menjadi kata-kata dan tindakan, sumber data tertulis, dokumentasi, dan statistik (Moelong, 2006). Dalam penelitian ini data yang diambil 
bersumber dari kata-kata dan tindakan yang berkaitan dengan penguatan yang dilakukan oleh guru bahasa Jepang dalam pembelajaran bahasa Jepang di SMA Negeri Bali Mandara akan diperoleh melalui kegiatan observasi, dokumentasi dan wawancara. Kata-kata dan tindakan orangorang yang diamati atau diwawancarai merupakan sumber data utama yang dicatat tertulis. Sumber data lainnya yaitu berupa foto yang diperoleh melalui kegiatan dokumentasi terhadap penguatan yang dilakukan oleh guru bahasa Jepang dalam pembelajaran bahasa Jepang di SMA Negeri Bali Mandara.

Dalam penelitian ini, pengumpulan data yang dilakukan yaitu dengan cara observasi, dokumentasi dan wawancara. Berikut merupakan pemaparan metode yang digunakan mencatat hal penting yang disampaikan oleh narasumber (Sugiyono, 2009:233).

a. Observasi

Metode observasi adalah kegiatan untuk memperoleh hasil berupa ruang

(tempat, pelaku, kegiatan, objek, perbuatan, kegiatan atau peristiwa waktu dan perasaan

(Darmadi, 2014). Dalam penelitian ini observasi dilakukan untuk memperoleh data mengenai model-model penguatan dan penggunaan bahasa Jepang dalam penguatan yang dilakukan oleh guru bahasa Jepang dalam pembelajaran bahasa Jepang di SMA Negeri Bali Mandara.

b. Dokumentasi

Kegiatan pengumpulan data juga didukung dengan teknik dokumentasi menggunakan kamera dengan hasil berupa foto sebagai bukti dan agar lebih memperjelas kegiatan memberikan penguatan yang dilakukan guru dalam pembelajaran, terutama penguatan bentuk nonverbal agar mempermudah dalam menganalisis data. c. Wawancara

Metode wawancara yang digunakan adalah wawancara semiterstruktur. Metode wawancara semiterstruktur adalah wawancara yang lebih bebas jika dibandingkan dengan wawancara terstruktur.

Dalam melakukan wawancara ini pewawancara secara teliti dalam mencatat hal penting yang disampaikan oleh narasumber (Sugiyono, 2009:233). Metode dan Teknik Analisis Data

Penelitian ini menggunakan teknik analisis data kualitatif oleh Miles dan Huberman (1994) dengan 3 aktivitas, yaitu: reduksi data, penyajian data, dan penarikan kesimpulan.

1. Reduksi data, dilakukan dengan mengumpulkan dan menyimak dialog yang diucapkan oleh guru bahasa

Jepang yang mengandung penguatan (reinforcement) verbal dan nonverbal dengan teknik catat, mengelompokkannya sesuai dengan model-model penguatan yang digunakan.

2. Penyajian data, dilakukan dalam bentuk teks naratif dengan menguraikan dialog yang telah dreduksi untuk selanjutnya dianalisis dengan melihat model yang digunakan. Serta melihat makna yang tergantung dalam kalimat dan konteks yang menyebabkan kalimat tersebut diungkapkan.

3. Penarikan kesimpulan, dilakukan setelah analisis data selesai dilakukan sehingga data menunjukkan bentuk penggunaan penguatan verbal dan nonverbal oleh guru bahasa Jepang dan hal yang memengaruhi hal tersebut.

\section{Hasil dan Pembahasan}

\section{A. Model-model Penguatan}

Dalam suatu proses pembelajaran terdapat dua kegiatan yang saling berkaitan satu sama lain yaitu mengajar dan belajar. Pembelajaran merupakan suatu proses seseorang yaitu siswa yang belum terdidik menjadi terdidik dengan cara mengikuti kegiatan pembelajaran yang dapat membuatnya menjadi memiliki pengetahuan (Aunurrahman, 2012). Pembelajaran juga dapat dikatakan merupakan suatu kegiatan yang dilakukan untuk mendorong siswa belajar sehingga dapat membangun pemahaman siswa dan dapat mencapai tujuan pembelajaran yang diingikan. Usahausaha untuk mendorong siswa belajar merupakan salah satu peran penting seorang guru. Seorang guru mempunyai peran untuk selalu dapat menjaga dan meningkatkan motivsi siswa untuk belajar. Pemberian motivasi ini salah satunya adalah dengan memberikan siswa penguatan yang merupakan salah satu keterampilan dasar mengajar yang harus dikuasai dan mampu diterapkan oleh guru profesional. 
Guru bahasa Jepang SMA Negeri Bali Mandara dalam pembelajaran menggunakan penguatan verbal maupun nonverbal. Penguatan biasanya diberikan secara bervariasi. Beberapa variasi penguatan yang dilakukan oleh guru yaitu penguatan verbal baik dalam bentuk kata maupun kalimat dan penguatan nonverbal dalam bentuk penguatan berupa mimik dan gerak badan (gestural), penguatan dengan cara mendekati, dan penguatan dengan kegiatan menyenangkan. Guru bahkan menggunakan kombinasi penguatan, yaitu menggunakan penguatan verbal dengan mendekati, verbal dengan gestural atau gerak badan, serta verbal dengan mendekati dan gestural. Dalam memberikan penguatan, guru menggunaan variasi bahasa dan campur kode dalam memberikan penguatan verbal dan kombinasi penguatan verbal dengan nonverbal sesuai dengan perilaku yang ditunjukkan siswa.

Bahasa yang digunakan adalah bahasa Indonesia, bahasa Jepang dan bahasa Bali. Bahasa Indonesia digunakan karena bahasa nasional siswa adalah bahasa Indonesia, sehingga mempermudah komunikasi antara guru dan siswa. Bahasa Jepang digunakan untuk membiasakan siswa dalam mendengar bahasa Jepang, menambah kosakata baru dan tentu saja dapat belajar lebih banyak mengenai bahasa Jepang. Selanjutnya bahasa pertama siswa SMA Negeri Bali Mandara adalah bahasa Bali. Penguatan dengan bahasa Bali diberikan untuk menegur siswa yang menunjukkan kegiatan yang tidak mendukung kegiatan pembelajaran. Kegiatan siswa yang biasa ditegur guru adalah mengobrol, ribut dan tidak mengikuti pembelajaran dengan baik. Penguatan ini diberikan dengan mengkombinasikan penguatan verbal dalam bahasa Bali dengan penguatan nonverbal atau penguatan mendekati.

\section{1). Penguatan Verbal}

Penguatan verbal yang dilakukan guru bahasa Jepang di SMA Negeri Bali Mandara dalam pembelajaran bahasa Jepang berupa kalimat. Penguatan verbal yang digunakan oleh guru berdasarkan pengamatan yang telah dilakukan sebanyak 38 kali, dan banyak penguatan verbal yang digunakan guru dengan cara mengkombinasikannya dengan penguatan nonverbal. Guru memberikan penguatan berupa kalimat "Hai oke, hari ini kita lanjut ke materi selanjutnya pada bab selanjutnya". Penguatan ini merupakan respons positif yang diberikan guru kepada kelompok siswa. Guru memberikan penguatan ini untuk mengonfirmasi usaha siswa, agar perilaku tersebut dapat dipertahankan dan diulangi. Respons positif ini digunakan saat siswa terlihat serius dan fokus dalam mengikuti pembelajaran serta dapat cepat memahami dan menjawab mengenai pengulangan materi sebelumnya. Penguatan-penguatan yang diberikan guru pada kegiatan awal tersebut, termasuk dalam respons positif yang bertujuan untuk mempertahankan dan meningkatkan perilaku yang telah ditunjukkan oleh siswa, sehingga perilaku tersebut dapat diulangi lagi (Barnawi \& Arifin, 2012 : 208).

Pada kegiatan inti pembelajaran guru memberikan penguatan verbal berupa kalimat "Ya, pertanyaan yang bagus!". Kalimat ini merupakan respons positif yang diberikan guru kepada siswa. Tujuan pemberian penguatan ini adalah untuk mengapresiasi atau memuji pertanyaan siswa. Hal ini dilakukan pada saat siswa bertanya kepada guru mengenai hal yang tidak dipahaminya. Penguatan ini diberikan kepada siswa secara individu. Seperti penelitian yang telah dilakukan oleh Yudayanti, dkk (2014) penguatan positif dapat meningkatkan keterampilan siswa dalam berkomunikasi interpersonal. Respons dari guru berupa konfirmasi, dukungan, pujian dapat membuat siswa menjadi akrab dengan guru sehingga menjadi aktif dalam kegiatan pembelajaran baik bertanya dan menyampaikan pendapat. Penguatan tersebut langsung diberikan pada siswa secara individu agar mereka merasa dihargai dan diperhatikan.

Penguatan verbal berupa kalimat, "Kalimatnya tidak salah tetapi, masak ke sekolah menggunakan kapal laut?". Kalimat ini merupakan respons negatif tidak penuh yang diberikan guru pada siswa. Tujuan guru memberikan respons tersebut untuk menanggapi usaha siswa, agar tidak takut dalam mencoba lagi, serta dapat mempertahankan motivasinya. Penguatan dengan bahasa Indonesia digunakan karena bahasa nasional siswa adalah bahasa Indonesia, sehingga mempermudah komunikasi antara guru dan siswa. 
Penguatan ini dilakukan pada saat siswa mencoba membuat kalimat, tetapi dalam kontek yang kurang tepat, sehingga kalimat tersebut menjadi tidak nyambung. Setelah itu, guru meminta siswa untuk menyesuaikan kontek kalimatnya dengan kenyataan yang ada dalam kehidupan siswa sehari-hari. Jenis penguatan yang digunakan guru adalah penguatan tidak penuh. Penguatan ini dilakukan guru, agar siswa dapat mengetahui bahwa jawabannya tidak sepenuhnya salah. Dalam keadaan ini, guru dapat meminta siswa lain untuk menjawab atau guru juga dapat membantu siswa mengetahui jawaban yang tepat, sehingga siswa dapat mengetahuinya (Hasibuan dkk, 1994).

\section{2). Penguatan Nonverbal}

Penguatan nonverbal yang digunakan guru dalam pembelajaran bahasa Jepang terdiri dari berbagai jenis seperti anggukan kepala, senyuman, tepuk pundak, sentuhan dan lain sebagainya. Tetapi dari data hasil observasi yang dilakukan sebanyak 4 kali, ditemukan guru lebih banyak menggunakan penguatan nonverbal berupa mimik dan gerak badan (gestural), penguatan mendekati dan penguatan kegiatan yang menyenangkan. Sedangkan penguatan sentuhan, penguatan dengan berupa simbol atau benda (token) tidak tampak digunakan dalam proses pembelajaran bahasa Jepang. Guru mengatakan bahwa penguatan seperti anggukan kepala, senyuman dan mendekati lebih banyak dilakukan, agar siswa merasa diperhatikan, dihargai keberadaannya dan prilakunya dapat dikonfirmasi, mengingat siswa SMA Negeri Bali Mandara tinggal di asrama dan jarang dapat berkumpul dengan keluarganya.

Pemberian penguatan nonverbal dilakukan untuk mengapresiasi serta menyetujui jawaban yang diucapkan atau dibacakan oleh siswa. Penguatan dilakukan pada saat kegiatan inti pembelajaran, ketika guru melatih siswa dan diberikan secara perorangan. Guru biasanya lebih banyak mengkombinasikan penguatan nonverbal dengan penguatan verbal agar makna penguatan dapat tersampaikan, sehingga dapat berdampak lebih signifikan bagi siswa.

a. Penguatan Gestural

Penguatan gestural yang digunakan guru berdasarkan hasil

pengamatan, dilakukan sebanyak 4 siswa. Guru memberikan penguatan kali, yaitu berupa anggukan kepala ini selain untuk memperhatikan dan dan senyuman. Penguatan ini mengecek, tetapi juga untuk merupakan respons positif yang memastikan bahwa semua siswa diberikan guru kepada siswa. Guru berada dalam kondisi siap dan memberikan penguatan ini untuk mampu dalam menjawab soal mengapresiasi serta menyetujui latihan, tugas, atau dapat jawaban yang diucapkan atau mendengarkan audio yang diputar. dibacakan oleh siswa. Penguatan ini Penguatan ini dilakukan saat latihan, dilakukan pada saat kegiatan inti kegiatan inti pembelajaran.

pembelajaran, ketika guru melatih Penguatan mendekati lebih siswa dan diberikan secara banyak ditujukan sebagai bentuk perorangan. penanganan guru terhadap siswa

Penguatan gestural berupa secara individu maupun kelompok. senyuman dilakukan oleh guru, Hal ini dilakukan agar siswa paham ketika siswa salah membuat kontek bahwa usahanya telah dikonfirmasi kalimat yaitu "April-san dan Oka-san oleh guru. Dengan pemberian datang dari toilet". Guru memberikan penguatan mendekati dapat penguatan ini untuk mengonfirmasi memberikan kesan perhatian dan usaha yang dilakukan oleh siswa dukungan guru bagi kegiatan yang dalam mencoba membuat kalimat dilakukan oleh siswa, sehingga baru. Penguatan ini diberikan agar kegiatan yang dilakukan oleh siswa siswa tidak merasa takut untuk baik dalam kelompok maupun mencoba lagi dan mempertahankan individu dapat terarah dan dapat motivasi siswa. Respons ini diberikan berjalan dengan baik. pada saat guru mendrill siswa untuk

membuat kalimat baru dan diberikan c. Penguatan dengan Kegiatan yang pada siswa secara perorangan. Menyenangkan dilakukan

Penguatan dengan kegiatan b. Penguatan Mendekati yang menyenangkan dapat 
Penguatan mendekati dengan berbagai cara yang dapat berdasarkan hasil pengamatan pada memberikan kesan pujian, guru dilakukan hanya sebanyak 7 pengakuan, dukungan, dan kali. Penguatan mendekati lainnya penghargaan kepada siswa. banyak dikombinasikan dengan Sehingga siswa dapat merasa verbal dan gestural oleh guru. bangga serta mempertahankan, Penguatan ini merupakan respons meningkatkan motivasi yang positif yang diberikan guru kepada dimilikinya. Berdasarkan siswa. Guru melakukan penguatan pengamatan, penguatan berupa mendekati untuk menunjukkan kegiatan yang menyenangkan yang kepedulian, mengecek dan dilakukan guru bahasa Jepang di mengoreksi catatan atau latihan yang SMA Negeri Bali Mandara dilakukan dibuat oleh siswa, agar motivasi sebanyak 2 kali. Penguatan dengan siswa dapat dipertahankan. kegiatan menyenangkan dilakukan Penguatan ini diberikan kepada dengan siswa membaca latihan siswa yang masih membaca dengan tugas di depan kelas. Penguatan ini terbata-bata dan ragu-ragu saat adalah respons positif yang diberikan kegiatan inti pembelajaran. oleh guru kepada siswa.

Penguatan nonverbal berupa memberikan penguatan mendekati merupakan respons menyenangkan tersebut untuk positif yang diberikan guru kepada mengapresiasi usaha yang telah dilakukan siswa yang sudah rajin dalam membuat tugas individu. Penguatan ini diberikan agar siswa mau mempertahankan, mengulangi perilakunya dan dapat menginspirasi teman-temannya, seperti pendapat Hasibuan dkk (1994:61) yang menyatakan bahwa, akan lebih bermakna lagi bila kegiatan dan tugas-tugas yang digunakan sebagai penguatan berhubungan dengan penampilan yang diberikan penguatan.

Penguatan dengan kegiatan menyenangkan berupa menonton anime bersama-sama di dalam kelas. Penguatan ini merupakan respons positif yang diberikan guru kepada siswa. Guru memberikan penguatan tersebut untuk mengapresiasi kerjasama siswa yang fokus, serius dalam mengikuti kegiatan pembelajaran, sehingga materi dapat selesai dibahas dengan waktu yang lebih cepat dari sebelumnya.

Respons positif ini dilakukan ketika materi pelajaran telah selesai dibahas. Penguatan dengan kegiatan menyenangkan berupa menonton anime dilakukan oleh guru dan seluruh siswa yang mengikuti pembelajaran. Dalam penguatan ini siswa dapat memilih anime yang ingin ditonton bersama-sama di depan kelas. Penguatan ini diberikan tentunya tidak hanya untuk bersenang-senang, tetapi juga dapat melatih pendengaran siswa tentang bahasa Jepang, menambah kosakata dan belajar mengenai kehidupan orang Jepang sesuai dengan pendapat dari Djamariah (2005:121) yaitu guru perlu memperhatikan dalam kegiatan atau tugas yang memiliki relevansi dengan tujuan pembelajaran yang dibutuhkan siswa.

\section{3). Kombinasi Penguatan}

Barnawi dan Arifin (2012:209) menyebutkan bahwa penguatan gestural sering kali digunakan dengan penguatan verbal. Sedangkan Djamariah (2005:121) menyatakan bahwa penguatan mendekati dapat digunakan untuk memperkuat penguatan verbal, tanda dan sentuhan. Dengan melakukan kombinasi penguatan, dapat meningkatkan makna dari penguatan yang guru berikan, sehingga dapat berdampak lebih signifikan bagi siswa. Kombinasi penguatan antara penguatan verbal dengan nonverbal dilakukan secara bervariasi oleh guru. Berdasarkan data observasi sebanyak 4 kali pertemuan ditemukan bahwa guru mengkombinasikan penguatan verbal dengan penguatan nonverbal seperti anggukkan kepala, senyuman, mendekati atau sebagainya untuk memberikan apresiasi dalam bentuk penghargaan, pujian dan pengakuan terhadap usaha siswa dalam menjawab pertanyaan yang diberikan oleh guru, melakukan intruksi yang diberikan oleh guru dan atas peran aktif siswa dalam proses pembelajaran. Dalam memberikan penguatan, guru juga menggunaan variasi bahasa dan campur kode dalam memberikan kombinasi penguatan verbal dengan nonverbal sesuai dengan perilaku yang ditunjukkan siswa.

\section{a. Kombinasi Penguatan Verbal dan Gestural}

Kombinasi penguatan verbal dan gestural dilakukan guru dengan mengkombinasikan penguatan verbal dengan penguatan gestural berupa senyuman dan anggukan kepala. Berdasarkan pengamatan yang telah dilakukan, kombinasi penguatan ini dilakukan guru 
sebanyak 126 kali. Penggunaan kombinasi penguatan verbal dengan gerak badan (gestural) sesuai dengan pendapat yang disampaikan oleh Barnawi dan Arifin (2012:209) yang menyatakan bahwa, penguatan mimik wajah dengan gerak badan (gestural) sering kali dilakukan dengan penguatan verbal.

Penguatan verbal berupa kalimat "Hai, ii desu ne, Mariati san" dan dikombinasikan dengan penguatan gestural berupa senyuman dan anggukan kepala. Penguatan ini merupakan respons positif. Guru memberikan penguatan tersebut untuk mengapresiasi dan memberi persetujuan terhadap penjelasan siswa. Guru menyatakan, penguatan bahasa Jepang digunakan untuk membiasakan siswa dalam mendengar bahasa Jepang, menambah kosakata baru dan tentu saja dapat belajar lebih banyak mengenai bahasa Jepang. Penguatan ini dilakukan pada saat kegiatan inti pembelajaran, ketika siswa mencoba menjadi tutor sebaya menjelaskan mengenai materi sebelumnya sesuai pemahamannya untuk teman-temannya yang dispen. Respons positif diberikan langsung kepada siswa secara individu.

Guru melakukan kombinasi penguatan verbal berupa kalimat "Hai, sangat tenang kalau dengan Wulan chan" dengan penguatan gestural berupa senyuman dan anggukan kepala. Penguatan tersebut merupakan respons positif. Guru memberikan penguatan ini untuk mengapresiasi, memuji dan menyetujui jawaban siswa dengan kehangatan yang ditunjukkan dengan senyuman. Hal ini diberikan agar siswa mempertahankan dan mengulangi perilaku positif pada kegiatan selanjutnya. Guru menyatakan campur kode bahasa Jepang dan bahasa Indonesia dilakukan untuk mempermudah komunikasi antara guru dan siswa mengingat bahasa nasional siswa adalah bahasa Indonesia, membiasakan siswa untuk mendengar penguatan dalam bahasa Jepang, sehingga siswa akan mengetahui apa makna dari penguatan yang diberikan.

Penguatan ini diberikan langsung kepada siswa secara individu, ketika siswa dapat menjawab dengan baik dan jelas dengan pembawaan yang tenang.

b. Kombinasi penguatan Verbal dan Mendekati

Berdasarkan pengamatan yang dilakukan selama observasi, kombinasi penguatan verbal dan mendekati dilakukan guru sebanyak 19 kali. Guru mengkombinasikan penguatan verbal berupa kalimat "Hai sou desune" dengan penguatan mendekati. Penguatan ini merupakan respons positif yang diberikan guru kepada siswa. Guru memberikan respons ini untuk mengonfirmasi dan memuji jawaban siswa. Penguatan tersebut dilakukan guru pada kegiatan inti pembelajaran saat siswa berlatih menyebutkan kosakata atau menjawab soal. Respons ini diberikan langsung kepada siswa secara individu.

Guru melakukan kombinasi penguatan verbal berupa kalimat "Yoku dekita" dengan penguatan mendekati. Penguatan ini merupakan respons positif. Guru melakukan penguatan ini untuk mengapresiasi dan menunjukan perhatian kepada siswa, guru berharap agar perilaku positif siswa dapat dipertahankan dan ditunjukkan kembali pada kegiatan selanjutnya. Penguatan ini diberikan dalam bahasa Jepang untuk membiasakan siswa dalam mendengar bahasa Jepang, menambah kosakata baru dan tentu saja dapat belajar lebih banyak mengenai bahasa Jepang. Guru memberikan respons positif ini pada saat siswa dapat membuat kalimat dan dengan baik, ketika kegiatan inti pembelajaran yang diberikan kepada siswa secara individu. Dengan memberikan peguatan seperti ini diharapkan siswa terus mempertahankan dan menunjukkan keaktifannya saat kegiatan pembelajaran berlangsung, karena respons positif yang diberikan guru pada perilaku positif siswa akan membuat perilaku tersebut terulang kembali (Barnawi dan Arifin,

2012:208).

Guru mengkombinasikan penguatan verbal seperti, "Wa, pat, nem, tus, dasa, tetap rame ya!" dan penguatan mendekati. Penguatan ini merupakan respons negatif. Dengan pemberian teguran ini, guru berharap siswa dapat menyadari bahwa kebiasaannya harus segera dirubah dan diperbaiki, sehingga tidak akan mengganggu teman lain dalam belajar dan tidak mendapat teguran lagi dari guru. Guru menyatakan, penguatan teguran diberikan dalam bahasa Bali, karena mengingat bahasa pertama siswa merupakan bahasa Bali, sehingga siswa menjadi malu untuk mengulangi perilaku negatif tersebut dan dapat 
memberikan kesan santai dan kekeluargaan seperti menegur anak sendiri. Hal ini tidak akan membuat siswa menjadi tersinggung, tetapi malu sampai ketahuan mengoblol atau lain-lain lagi. Respons ini diberikan ketika kegiatan inti pembelajaran yaitu saat latihan tanya jawab, tetapi siswa sibuk mengobrol dan ribut. Teguran yang dilakukan guru berupa kalimat tegas sesuai dengan kesalahan siswa (Djamariah dan Zain, 2006:156).

\section{Kombinasi Penguatan Verbal, Gestural, dan Mendekati}

Berdasarkan pengamatan yang dilakukan selama observasi, kombinasi penguatan verbal, gestural, dan mendekati dilakukan guru sebanyak 96 kali. Kombinasi penguatan yang dilakukan guru adalah kombinasi penguatan verbal dengan mendekati, penguatan gestural berupa senyuman dan anggukkan kepala. Penguatan ini diberikan kepada siswa baik secara individu maupun kelompok pada saat kegiatan inti pembelajaran yaitu ketika latihan menyebutkan kosakata, membaca wacana, mentranslite kalimat, membuat kalimat dan sebagainya.

Penguatan diberikan sebagai bentuk perhatian guru, senang dan puas atas usaha yang dilakukan oleh siswa, konfirmasi ini dilakukan sesuai dengan kebenaran jawaban siswa, pujian terhadap keberhasilan siswa dalam berlatih, serta untuk memberi penekanan bahwa guru melakukan perhatian dan konfirmasi secara individu terhadap siswa yang diberikan penguatan sekaligus untuk memperjelas kata-kata atau kalimat yang diucapkan siswa. Penguatan ini diberikan dengan cara mendekati siswa yang sedang mendapatkan giliran berlatih, setelah itu diberikan penguatan berupa verbal dan gestural berupa anggukan kepala dan senyuman secara satu-persatu (Hasibuan dkk, 1994:60). Penguatan verbal yang diberikan berupa "Hai Devi-san" atau "Hai Jeni-san" atau "Hai, ii desu" diberikan kepada siswa yang sudah menjawab dengan benar saat berlatih dan "Hai, Aries san, watashi wa kuruma de gakkou e ikimasu" ketika siswa salah dalam menggunakan alat transportasi yaitu denwa (telepon) dan langsung diperbaiki oleh guru tanpa menyalahkan siswa. Penguatan seperti ini langsung diberikan saat guru masih berada di dekat siswa agar siswa tidak takut untuk mencoba membuat kalimat baru lagi dan siswa dapat merasa akrab dengan guru dan berani untuk berkomunikasi lebih banyak

(Yudayanti dkk, 2014).

Guru juga memberikan penguatan berupa kombinasi penguatan verbal dengan mendekati dan penguatan gestural berupa senyuman dan anggukan kepala, saat siswa mau menyampaikan pendapatnya berupa pertanyaan dan jawaban. Penguatan verbal yang diberikan berupa, "Ya benar sekali, ketika $\mathrm{n}$ ditambah $\mathrm{p}$ maka akan dibaca $\mathrm{m}$, seperti sampo shimasu dan empitsu" atau "Ya, hanya untuk aimasu tidak menggunakan partikel wo tetapi ni, karena aimasu adalah kata kerja spesial" penguatan ini diberikan ketika siswa bertanya. Penguatan verbal berupa, "Hai, ii desu pande san", "Hai sou desune Pandesan sugoi desu" diberikan untuk mengkonfirmasi siswa yang memberi pendapat berupa jawaban benar dan mampu membuat kalimat baru dengan tepat. Guru memberikan penguatan dengan bahasa Jepang untuk membiasakan siswa dalam mendengar bahasa Jepang, menambah kosakata baru dan tentu saja dapat belajar lebih banyak mengenai bahasa Jepang. Penguatan ini dilakukan dengan menyebut nama siswa secara langsung agar siswa merasa dihormati dan dihargai dan merasa usahanya telah dikonfirmasi dengan baik (Hasibuan dkk, 1994:57).

Tidak hanya itu, guru juga mengkonfirmasi usaha siswa yang rajin dan mau membantu, guru memberikan penguatan verbal berupa, "Hai, arigatou gozaimasu Adi san sudah mau membantu teman yang lain mengingat materi sebelumnya" dan "Soudesune, sugoidesu!, ini baru K13, saya sedikit berbicara". Dalam memberikan penguatan ini, guru menggunakan campur kode bahasa Jepang dan bahasa Indonesia. Guru menyatakan, hal ini dilakukan untuk mempermudah komunikasi antara guru dan siswa mengingat bahasa nasional siswa adalah bahasa Indonesia, membiasakan siswa untuk mendengar penguatan dalam bahasa Jepang, sehingga siswa akan mengetahui apa makna dari penguatan yang diberikan, dan menciptakan suasana pelajaran bahasa Jepang yang tidak kaku, mengingat pembelajaran bahasa Jepang adalah bahasa asing yang masih diajarkan pada tingkat dasar.

Penguatan ini diberikan oleh guru secara perorangan, karena siswa sudah mau membantu guru dan siswa yang jarang hadir karena mengikuti kegiatan lain di luar sekolah. 
Penguatan seperti ini diberikan agar usaha seperti ini dapat dipertahankan, dikembangkan dan serta dimunculkan oleh siswa yang bersangkukan dan juga dapat menginspirasi teman yang lainnya. Kemampuan siswa yang diakui oleh guru dan teman-temannya dapat membuat siswa tesebut dapat meningkatkan rasa percaya dirinya dari sebelumnya (Djamariah,

2005:118).

Selain itu guru juga memberi teguran dengan menggunakan kombinasi penguatan verbal dengan mendekati dan penguatan gestural berupa senyuman dan anggukan kepala. Penguatan verbal yang digunakan berupa, "Kalian jarang menulis dengan huruf kana ya, saya harap tulisan romajinya diganti dengan huruf kana ya". Penguatan ini diberikan kepada seluruh siswa, karena guru masih menemukan siswa yang menulis dengan huruf romaji ketika latihan. Penguatan verbal berupa teguran lain seperti, "Hai, kalian menggunakan bahasa Indonesia saja masih belepotan ya!".

Ketika siswa menterjemahkan kalimat dalam bahasa Jepang ke bahasa Indonesia dengan salah.

\section{B. Penggunaan bahasa Jepang dalam}

Penguatan

Berdasarkan hasil observasi dan wawancara yang telah dilakukan terhadap guru bahasa Jepang dalam pembelajaran bahasa Jepang di SMA Negeri Bali Mandara menunjukkan bahwa penggunaan bahasa Jepang yang dilakukan guru dalam penguatan lebih banyak menggunakan penguatan bentuk verbal. Guru banyak menggunakan pujian, persetujuan, pengakuan dukungan, nasihat dan teguran dalam bahasa Jepang yang dicampur kode dengan bahasa Indonesia.

Ungkapan bahasa Jepang yang sering digunakan guru untuk memberi penguatan pada perilaku positif yang ditunjukkan siswa yaitu berupa kata "Hai", "Hai, ii desu", "Hai, soudesune", "Hai daijyoubu desu", "Arigatou gozaimasu", dan "Otsukaresamadeshita". Guru sering menggunakan kata atau kalimat dalam bahasa Jepang unuk memuji, memberikan persetujuan, dukungan dan penghargaan terhadap jawaban siswa, usaha siswa, hasil kerja siswa, dan inisiatif siswa serta keaktifan siswa di kelas. Selain itu ada juga ungkapan bahasa Jepang yang digunakan guru untuk menasehati atau menegur siswa yang menunjukkan perilaku negatif yang dapat mengganggu kegiatan pembelajaran. Ungkapan verbal bahasa Jepang yang digunakan berupa "Diam-diam shizukani!" yang dicampur kode dengan bahasa Indonesia. Campur kode dengan bahasa Indonesia digunakan untuk menegaskan kalimat dalam bahasa Jepang, sehingga siswa dapat memahami penguatan dengan baik. Selain itu dari penguatan yang diberikan guru, siswa dapat mengulangi atau menambah kosakata baru yang dimilikinya.

Selain itu pemberian penguatan "Arigatou gozaimashita" ketika mengapresiasi keaktifan dan inisiatif siswa dalam pembelajaran serta penguatan "Otsukaresamadeshita" ketika mengakhiri kegiatan pebelajaran sebagai bentuk apresiasi atas partisipasi siswa selama pembelajaran berlangsung. Guru bahasa Jepang SMA Negeri Bali Mandara menyatakan bahwa, dengan menyisipkan atau menggunakan bahasa Jepang dalam memberi penguatan ketika proses pembelajaran, selain untuk menjaga dan meningkatkan motivasi siswa, menambah pengetahuan siswa tentang kejepangan dan tentu saja untuk menambah penguasaan kosakata bahasa Jepang siswa.

Dengan demikian dapat disimpulkan bahwa penggunaan bahasa Jepang dalam penguatan pada saat kegiatan pembelajaran dilakukan guru dengan cara menggunakan penguatan verbal dalam bentuk pujianpujian, dukungan, pengakuan, dan penghargaan dalam bahasa Jepang berupa ungkapan "Hai", "Hai, iidesu", "Hai, soudesune", "Hai, daijyoubudesu", "Arigatou gozaimashita", dan "Otsukaresamadeshita". Selain itu ada juga ungkapan bahasa Jepang yang digunakan guru untuk menasehati atau menegur siswa yang menunjukkan perilaku negatif berupa ungkapan verbal bahasa Jepang yang digunakan berupa “Diam-diam shizukani!" yang dicampur kode dengan bahasa Indonesia.

\section{Simpulan dan Saran}

Jurnal Pendidikan Bahasa Jepang | 158 
Guru bahasa Jepang dalam pembelajaran bahasa Jepang di SMA Negeri Bali Mandara menggunakan beberapa variasi penguatan, yaitu penguatan verbal baik berupa kata dan kalimat. Penguatan nonverbal baik berupa gerak badan (gestural) berupa senyuman, menganggukkan kepala, mendekati, dan dengan kegiatan yang menyenangkan. Guru juga menggunakan kombinasi penguatan verbal dan nonverbal tersebut. Penguatan digunakan dalam bentuk pujian-pujian, dukungan, pengakuan, dan penghargaan, serta dalam bentuk teguran dan nasihat. Penguatan berupa symbol atau benda (token) tidak tampak digunakan guru dalam pengamatan yang telah dilakukan, karena penguatan berupa tidak dapat diberikan karena terbatasnya waktu.

Penggunaan bahasa Jepang dalam penguatan dilakukan guru dengan cara menggunakan penguatan verbal dalam bentuk pujian-pujian, dukungan, pegakuan, dan penghargaan, dalam bahasa Jepang berupa "Hai", "Hai, iidesu", "Hai, soudesu", "Sugoi desu", "Yoku dekita", "Daijyobu desu",

"Arigatou gozaimashita", dan

"Otsukaresamadeshita", serta memberikan penguatan dalam bentuk nasehat atau teguran berupa "Diam-diam shizukani".

\section{Daftar Pustaka}

Aryawan, I M. A. S. 2017. "Penguatan dalam Bahasa Jepang oleh Guru Bahasa Jepang SMA Negeri 1 Sukasada" Skripsi (tidak diterbitkan). Jurusan Pendidikan Bahasa Jepang, Undiksha Singaraja.

Aunurrahman. 2012. Belajar dan Pembelajaran. Bandung; Alfabeta.

Barnawi dan Arifin 2012. Etika dan Profesi Kependidikan. Cetakan Pertama. Yogyakarta: Ar-Ruzz Media.

Dantes, N. 2012. Metode Penelitian. Yogyakarta: Andi.

Darmadi, Hamid .2014. Metode Penelitian Pendidikan dan sosial. Bandung: Alfabeta.

Davies, RB. (1991) Teacher as Curricullum Evaluators. Sydney: George Allen and Unwin.

Djamariah, S. B. 2005. Guru dan Anak Didik dalam Interaksi Edukatif suatu Pendekatan Teoritis Psikologis. Cetakan Ketiga. Jakarta: PT Rineka Cipta.

Djamariah, S. B. dan Zain Aswan. 2006. Strategi Belajar-mengajar. Cetakan Ketiga. Jakarta: PT Adi Mahasatya.

Hasibuan ddk. 1994. Proses Belajar Mengajar Keterampilan Dasar Pengajaran Mikro. Cetakan ketiga. Bandung: PT Remaja Rosdakarya.

Miles, Matthew B. dan A. Michael Huberman. 1994. Qualitative Data Analysis Second Edition. United State of America: Sage Publications.

Moelong, L. J. 2006 Metodelogi Penelitian Kualitatif. Bandung: PT Remaja Rosdakarya.

Sugiyono. 2009. Metode Penelitian Kuantitatif, Kualitatif, $R$ dan D. Cetakan Ketujuh. Bandung: CV. Alfabet.

Turney, C. ddk. 1973. Sydney Micro Skill Handbook Series 1-5 Sydney ; Sydney University.

Usman, Moh. Uzer. 2005. Menjadi Guru Profesional. Cetakan ke-17. Bandung : Remaja Rosdakarya.

Utami, Ni Ketut Sri dkk. 2015. "Penguatan Verbal dan Nonverbal Guru Bahasa Indonesia dalam Melaksanakan

Pembelajaran Teks Cerpen di Kelas VIIG SMP N 1 Banjar". Skripsi (tidak diterbitkan). Jurusan Pendidikan Bahasa dan Sastra Indonesia, Undiksha Singaraja.

Yudayanti, Ni Luh Sri ddk. 2014. “Penerapan Konseling Kelompok dengan Teknik

Penguatan Positif untuk

Meningkatkan Keterampilan dalam Berkomunikasi Interpersonal Siswa Kelas X MIA 2 SMA Negeri 3 Singaraja". Tersedia pada 
JPBJ, Vol. 5 No. 2, Juli, 2019

ISSN: 2613-9618

http://ejournal.undiksha.ac.id/index.p hp/JJBK/article/viewFile/3657/2945 (diakses pada 20 april 2018). 